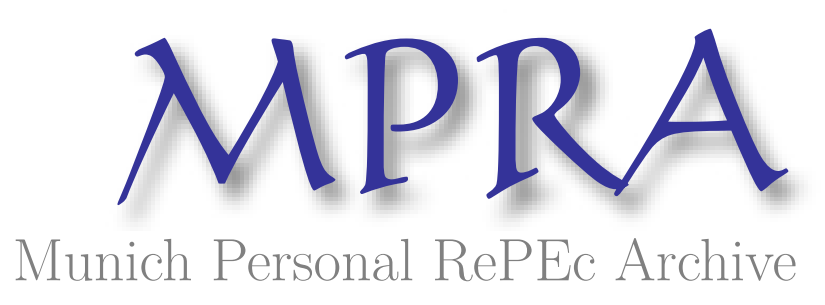

\title{
The Cost of Climate Change in 19th Century Europe.
}

Mayo, Robert

2014

Online at https://mpra.ub.uni-muenchen.de/98436/

MPRA Paper No. 98436, posted 01 Feb 2020 11:11 UTC 
The Cost of Climate Change in 19th Century Europe.

by

Robert L. Mayo

George Mason University

May 9, 2014 


\section{Introduction}

What should we do about climate change? This commonly asked question is predicated on answers to other questions, such as: Is climate change happening? If so, is that a bad thing? If so again, how bad of a thing is it? Sadly, the public and scientific discussion on this topic has produced far more heat than light. This paper is an attempt to shift that balance slightly towards light by providing an analysis of the economic cost of climate change across 19th century Europe.

The term "climate change" has partially displaced the term "global warming" in public and scientific discourse. The two terms are used interchangeably, but in a literal sense have very different meanings. Global warming means, obviously, that the temperature of the globe is rising. Climate change, however, does not specify a direction of change, although increase is generally implied. I attempt here to quantify the economic cost of environmental temperature change separate from direction of that change.

As part of the Intergovernmental Panel on Climate Change (IPCC) Third Assessment Report, Smith, et al. (2001) attempt to quantify the economic cost of projected increases in average global temperature of $2^{\circ} \mathrm{C}$, between 2 and $3^{\circ} \mathrm{C}$, and more than $3^{\circ} \mathrm{C}$. One of their main conclusions is the following:

"With a small temperature increase, there is medium confidence that aggregate market sector impacts would amount to plus or minus a few percent of world gross domestic product (GDP), and there is low confidence that aggregate nonmarket impacts would be negative." 
This presents two problems. 1) Use of the word "increase" does not make a distinction between the effect of the temperature changing to a higher level and the effect of the temperature being at a higher level, and 2) Stating with less than high confidence a predicted effect of either increasing or decreasing GDP by an unspecified amount contains essentially no information.

In 2007, Sir Nicholas Stern of the London School of Economics issued the "Stern Review on the Economics of Climate Change" which was commissioned by the UK government. The executive summary explains the anticipated cost of climate change as follows:

"[T]he overall costs and risks of climate change will be equivalent to losing at least 5\% of global GDP each year, now and forever. If a wider range of risks and impacts is taken into account, the estimates of damage could rise to $20 \%$ of GDP or more."

The Stern Report prediction of the cost of climate change is more specific than the prediction in the IPCC Third Assessment, but also fails to explicitly state whether the costs are imposed by the environmental temperature rising or by the temperature being at that higher level. Several of the underlying predictions of ecological change such as melting of the polar ice caps and resulting flooding are obviously a product of higher temperature, while others such as population migration following a shift in arable regions would be a product of temperature change, but not level.

II. Theory and Hypothesis

If environmental temperature change occurs and imposes costs, it stands to reason that less developed countries will have more difficulty paying those costs than will more developed, 
richer countries. Those costs, however, may not be uniformly distributed across the income spectrum. In order to understand the economic costs of temperature change on the societies least able to bear additional costs, it would be helpful to have a model. I propose that we can better understand the cost that climate change may impose on underdeveloped countries in the future by examining the cost imposed by climate change on developed countries in the past. Europe of the $19^{\text {th }}$ century in some ways resembled modern day under developed areas. In comparison to modern developed countries both have poor transportation infrastructure, few opportunities for improving human capital, and low levels of industrialization. Both economies are dominated by small farming, fishing, and animal husbandry primarily organized around the village. Large cities exist, but with poor sanitation and few public services.

Societies organize themselves to maximize output in a particular environment, but when conditions change this organization may no longer be optimal. In a village level agricultural setting, if the only changes required to maximize output at a new temperature were to plant and harvest on different dates, or to cultivate more of one crop and less of another, then this adjustment process could happen rapidly after the temperature change was noticed and the departure from maximum output would be brief. If, however, the adjustment process was more difficult then sub-optimal production would persist for a longer period. As a simple illustration, the Inuit living above the Arctic Circle do not attempt to grow orchids, neither do people living near the equator attempt to provide for their families through ice fishing. If the temperatures were suddenly reversed, both would suffer productivity losses proportional to the time required for each to start/stop ice fishing and plant/abandon orchids.

My hypothesis is that societies based largely around village level subsistence agriculture have their methods of production deeply embedded in their cultures and institutions and for this reason they will be slow to change and therefore a change in temperature in either direction, 
whether towards a climate more conducive to agricultural production or away from it, should impose a temporary efficiency loss. This prediction can be tested by comparing the gains in productivity following a temperature change with the losses in productivity following a temperature change in the opposite direction. If adjustment to the new temperature was instantaneous, then the absolute value of the gains in productivity caused by a change in temperature $\mathrm{T}$ from $\mathrm{T}(\mathrm{a})$ to $\mathrm{T}(\mathrm{b})$ should be the same as the absolute value of the efficiency losses caused by a change in temperature from $\mathrm{T}(\mathrm{b})$ to $\mathrm{T}(\mathrm{a})$. In the alternate case, if adjustment to the new temperature was not instantaneous, then the absolute value of the gains in productivity caused by a change in temperature from $\mathrm{T}(\mathrm{a})$ to $\mathrm{T}(\mathrm{b})$ should not be the same as the absolute value of the efficiency losses caused by change in temperature from $\mathrm{T}(\mathrm{b})$ to $\mathrm{T}(\mathrm{a})$. As an example, imagine the opposite of instantaneous adjustment; a society whose farming methods are fixed. Assume that a moderate increase (decrease) in temperature would raise (lower) the productive capacity of their land. If the temperature decreased, they would be unable to adjust their farming methods to mitigate the effect and would suffer a large efficiency loss. By contrast, if the temperature increased, they would be unable to adjust their farming methods to realize the new production opportunity. The magnitude of production change would be large in one direction and small in the other.

\section{Data}

To test this proposition I use two large data sets:

\section{A. NOAA Gridded April-September multiproxy European temperature reconstructions} for the last 1400 years. The National Oceanic and Atmospheric Administration (NOAA) makes publicly available a wide variety of temperature reconstructions spanning from a few hundred years to hundreds of thousands of years. This data set was produced by the World Data Center 
for Paleoclimatology, and the NOAA Paleoclimatology Program. Since reliable measuring technology was not available prior to the past few centuries, any climate data set of greater length must be a reconstruction using proxies. This data set is unusual in that it uses multiple proxies representing different dates and locations to provide wide geographic coverage as well as functioning as cross checks between data sources. The proxies used were tree growth rings, pollen residues, ice cores, and historical documents. The data lists temperatures from $600 \mathrm{AD}$ to 2000 AD represented as divergences from the 1961-1990 average for 100 locations in Europe. Data points are located on a $5^{\circ}$ latitude by $5^{\circ}$ longitude grid from $27.5^{\circ} \mathrm{N}$ to $72.5^{\circ} \mathrm{N}$ and from $7.5^{\circ} \mathrm{W}$ to $57.5^{\circ} \mathrm{E}$.

An analysis can only be as good as the data it is based on, and this paper is no exception. Given that I am not qualified to judge issues in the discipline of paleoclimatology, I present the data set's authors' assessment of accuracy.

“Methodology/Principal Findings: An original spectral analog method was devised to deal with this heterogeneous dataset, and to preserve longterm variations and the variability of temperature series. So we can replace the recent climate changes in a broader context of the past 1400 years. This preservation is possible because the method is not based on a calibration (regression) but on similarities between assemblages of proxies. The reconstruction of the April-September temperatures was validated with a Jackknife technique. It was also compared to other spatially gridded temperature reconstructions, literature data, and glacier advance and retreat curves. We also attempted to relate the spatial distribution of European temperature anomalies to known solar and volcanic forcings. Conclusions: We found that our results were accurate back to $750 . “$ 
B. Maddison Project Database. Dr. Angus Maddison was co-founder of the Growth and Development Centre at the University of Groningen, in The Netherlands. There he produced estimates of per capita GDP for a vast array of countries going back as far in some cases as two thousand years. After his death in 2010, a group of his colleagues created the Maddison Project to preserve and extend his work. The most recent update of the data was presented in Bolt and Van Zanden (2013) and is used here. Although this update includes 156 countries and regions starting at year $1 \mathrm{AD}$ and going to the present, it does not have data for every country for every year in that range. As to the accuracy of the GDP estimates, I rely on the high reputation of the late Dr. Maddison, his colleagues who continue his work, and the University of Groningen.

I filtered the list of countries represented in the Maddison Project data set to exclude those countries that did not have at least a continuous 50 year run of annual per capita GDP data between 1800 and 1899. Data that was outside this date range was much less complete and therefore discarded. A total of 10 countries remained: Belgium, Denmark, France, Germany, Italy, Holland, Norway, Sweden, Switzerland, and England/Britain/UK. The range of dates for data for each country is listed in table 1.

Table 1. Data date ranges.

\begin{tabular}{cc}
\hline Country & Data date range \\
\hline Belgium & $1848-1899$ \\
Denmark & $1820-1899$ \\
France & $1820-1899$ \\
Germany & $1850-1899$
\end{tabular}




\begin{abstract}
Italy $\quad 1802-1899$
Holland $\quad$ 1815-1899

Norway $\quad 1830-1899$

Sweden $\quad 1802-1899$

Switzerland $\quad 1851-1899$

England/Britain/UK 1801-1899
\end{abstract}

For each country, by visual inspection I selected the temperature data point closest to the country's geographic center and used this as the temperature corresponding to the per capita GDP for that country. The location of each temperature data point is shown in table 2 .

Table 2. Temperature data point locations

\begin{tabular}{cc}
\hline Country & Latitude/longitude \\
\hline Belgium & $7.5 \mathrm{~W} 52.5 \mathrm{~N}$ \\
Denmark & $7.5 \mathrm{~W} 57.5 \mathrm{~N}$ \\
France & $2.5 \mathrm{~W} 47.5 \mathrm{~N}$ \\
Germany & $12.5 \mathrm{~W} 52.5 \mathrm{~N}$ \\
Italy & $12.5 \mathrm{~W} 42.5 \mathrm{~N}$ \\
Holland & $7.5 \mathrm{~W} 52.5 \mathrm{~N}$ \\
Norway & $7.5 \mathrm{~W} 62.5 \mathrm{~N}$ \\
Sweden & $17.5 \mathrm{~W} 62.5 \mathrm{~N}$
\end{tabular}


Switzerland

England/Britain/UK
$7.5 \mathrm{~W} 47.5 \mathrm{~N}$

\section{$2.5 \mathrm{E} 52.5 \mathrm{~N}$}

\section{Methodology}

I calculated the change from the preceding year in per capita GDP growth rate and in temperature for each of the 10 countries. I separated this data into two groups for each country; years when the temperature increased and years when the temperature decreased. A very small number of years in the data showed exactly zero temperature change and were excluded from both groups. I then regressed growth rate of per capita GDP against temperature change for each of the 20 data groups. This generated intercept and slope parameters representing the effect of rising temperature on each country and the effect of declining temperature on each country. If re-optimization of methods of production to the new temperatures occurs faster than the 1 year time resolution of the data, then the absolute value of the slope parameter of the temperature rising regression for each country should equal the absolute value of the slope parameter of the temperature falling regressions for that country. I conducted a two tailed t-test on the two groups of slope parameters to determine if they were significantly different.

\section{Results}

The full results of the two regressions for each of the 10 countries are shown in appendix A. The slope parameters for temperature rising regressions (listed as $\beta 1$ ), and for temperature falling regressions (listed as $\beta 3$ ) for each country are shown in table 3. Summary statistics for signed and unsigned $\beta 1$ and $\beta 3$ are shown in table 4. T-test $p=0.98315$. 
Table 3. Regression slope parameters

\begin{tabular}{ccc}
\hline Country & $\beta 1$ & $\beta 3$ \\
\hline Belgium & -0.0134528 & 0.00820698 \\
Denmark & 0.0131619 & 0.0107846 \\
France & -0.0024607 & 0.00546814 \\
Germany & -0.0443883 & 0.0152699 \\
Italy & -0.00780892 & 0.0256177 \\
Holland & 0.0117346 & 0.00107493 \\
& & \\
Norway & 0.00533018 & -0.00956387 \\
Sweden & -0.00771691 & 0.0303337 \\
& & \\
\hline Switzerland & -0.00943865 & 0.00102638 \\
& & \\
\hline England/Britain/UK & 0.0339113 & 0.0433649 \\
\hline
\end{tabular}

Table 4. Summary statistics

\begin{tabular}{|c|c|c|c|c|}
\hline & \multicolumn{2}{|c|}{ Signed } & \multicolumn{2}{|c|}{ Absolute value } \\
\hline & $\beta 1$ & $\beta 3$ & $\beta 1$ & $\beta 3$ \\
\hline Mean & -0.00211 & 0.01316 & 0.01494 & 0.01507 \\
\hline Standard deviation & 0.02058 & 0.01587 & 0.01343 & 0.01385 \\
\hline
\end{tabular}




\section{Conclusion}

It would be expected that $\beta 1$ signed and $\beta 3$ signed would have opposite signs, and I find that is the case. Since $\beta 1$ signed is negative and $\beta 3$ signed is positive, it indicates that a change in temperature upwards reduces per capita economic growth and a change downward increases economic growth. This implies that these 10 countries are on average above the optimum temperature for production. Since the group includes two Nordic countries, this result is counter intuitive. One possible explanation would be that colder, harsher weather forces people away from farming and into other less weather dependent occupations such as village scale crafts or industrial employment in the cities.

The central of this paper is the $p$-value of the t-test on the absolute values of the $\beta 1$ group and $\beta 3$ group and shows that the means of the two groups are not significantly different. The implication of this result is that the production enhancing effect of a given temperature decline is equal in size to the production inhibiting effect of an equal temperature increase. Thus, there is no evidence of an efficiency loss due to slow restructuring of methods of production to maximize output at a new temperature.

In light of this result, I conclude that my hypothesis that societies based largely around village level subsistence agriculture will be slow to adapt production methods to a new climate environment and will therefore incur a temporary efficiency loss, is not supported. However, this result also implies that, should significant climate change occur in the future, under 
developed societies should be able to rapidly adapt production to accommodate the change without significant efficiency loss. 


\section{References}

Bolt, J. and J. L. van Zanden (2013). The First Update of the Maddison Project; Re-Estimating Growth Before 1820. Maddison Project Working Paper 4.

Calzadillaa,, Alvaro, Tingju Zhu, Katrin Rehdanz, Richard Toi and Claudia Ringler.

"Economywide impacts of climate change on agriculture in Sub-Saharan Africa." Ecological Economics 93 (2013): 150-165.

Ciscar, Juan-Carlos, Ana Iglesias and Luc Feyen. "Physical and economic consequences of climate change in Europe." Proceedings of the National Academy of Sciences of the United States of America 108(7) (2011): 2678-2683.

Hampicke, Ulrich. "Climate change economics and discounted utilitarianism." Ecological Economics 72 (2011): 45-52.

IPCC, 2007: Climate Change 2007: The Physical Science Basis. Contribution of Working Group I to the Fourth Assessment Report of the Intergovernmental Panel on Climate Change [Solomon, S., D. Qin, M. Manning, Z. Chen, M. Marquis, K.B. Averyt, M.Tignor and H.L. Miller (eds.)]. Cambridge University Press, Cambridge, United Kingdom and New York, NY, USA.

Rezai, Armon, Lance Taylor and Reinhard Michler. "Ecological macroeconomics: An application to climate change ." Ecological Economics 85 (2013): 69-76.

Salinas, Carla and Jon Mendieta. "Mitigation and adaptation investments for desertification and climate change: an assessment of the socioeconomic return." Mitigation and Adaptation Strategies for Global Change 18(5) (2013): 659-672.

Stern, Nicholas. "Stern Review on the Economics of Climate Change." The OK Government Web Archive. http://webarchive.nationalarchives.gov.uk/ /http:/www.hmtreasury.gov.uk/sternreview_index.htm (accessed May 10, 2014).

Victor, Peter. "Growth, degrowth and climate change: A scenario analysis." Ecological Economics 84 (2012): 206-121. 


\section{Appendix A.}

Belgium Increase

Model 1: OLS, using observations 1-31

Dependent variable: GROWTH_RATE

coefficient std. error t-ratio p-value

$\begin{array}{lrrrrr}\text { const } & 0.0167072 & 0.00377407 & 4.427 & 0.0001 \\ \text { TEMP_CHANGE } & -0.0134528 & 0.00760262 & -1.769 & 0.0873 & *\end{array}$

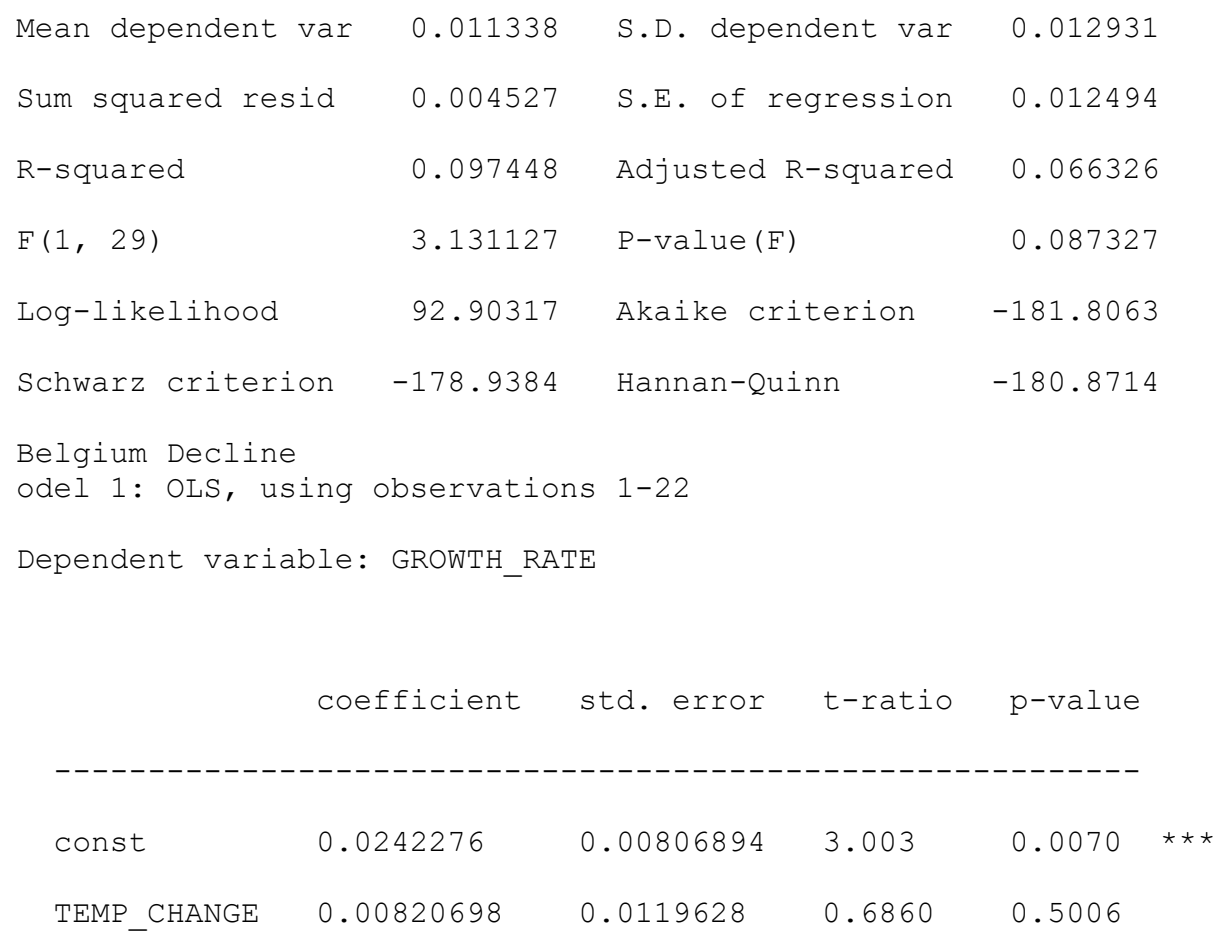

$\begin{array}{lclr}\text { Mean dependent var } & 0.019573 & \text { S.D. dependent var } & 0.020225 \\ \text { Sum squared resid } & 0.008393 & \text { S.E. of regression } & 0.020485 \\ \text { R-squared } & 0.022991 & \text { Adjusted R-squared } & -0.025859 \\ \text { F(1, 20) } & 0.470650 & \text { P-value (F) } & 0.500565 \\ \text { Log-likelihood } & 55.36890 & \text { Akaike criterion } & -106.7378 \\ \text { Schwarz criterion } & -104.5557 & \text { Hannan-Quinn } & -106.2238\end{array}$


Denmark Increase

Model 1: OLS, using observations 1-43

Dependent variable: GROWTH_RATE

coefficient std. error t-ratio p-value

$\begin{array}{lllll}\text { const } & 0.000762984 & 0.00753791 & 0.1012 & 0.9199 \\ \text { TEMP_CHANGE } & 0.0131619 & 0.00903390 & 1.457 & 0.1527\end{array}$

$\begin{array}{lcll}\text { Mean dependent var } & 0.009653 & \text { S.D. dependent var } & 0.029409 \\ \text { Sum squared resid } & 0.034537 & \text { S.E. of regression } & 0.029023 \\ \text { R-squared } & 0.049224 & \text { Adjusted R-squared } & 0.026035 \\ \text { F(1, 41) } & 2.122693 & \text { P-value(F) } & 0.152748 \\ \text { Log-likelihood } & 92.21471 & \text { Akaike criterion } & -180.4294 \\ \text { Schwarz criterion } & -176.9070 & \text { Hannan-Quinn } & -179.1305 \\ \text { Denmark Decline } & & & \\ \text { Model 1: OLS, using } & \text { observations } & 1-36 & \\ \text { Dependent variable: GROWTH_RATE } & \end{array}$

coefficient std. error t-ratio p-value

$\begin{array}{llllll}\text { const } & 0.0214736 & 0.00526880 & 4.076 & 0.0003 \\ \text { TEMP_CHANGE } & 0.0107846 & 0.00494054 & 2.183 & 0.0360 & * \star\end{array}$

$\begin{array}{lcll}\text { Mean dependent var } & 0.012670 & \text { S.D. dependent var } & 0.021409 \\ \text { Sum squared resid } & 0.014070 & \text { S.E. of regression } & 0.020343 \\ \text { R-squared } & 0.122918 & \text { Adjusted R-squared } & 0.097122 \\ \text { F(1, 34) } & 4.764922 & \text { P-value (F) } & 0.036046 \\ \text { Log-likelihood } & 90.16805 & \text { Akaike criterion } & -176.3361 \\ \text { Schwarz criterion } & -173.1691 & \text { Hannan-Quinn } & -175.2307\end{array}$


England Increase

Model 1: OLS, using observations 1-47

Dependent variable: GROWTH_RATE

coefficient std. error t-ratio p-value

$\begin{array}{lrrrr}\text { const } & 0.00937865 & 0.00816343 & 1.149 & 0.2567 \\ \text { TEMP_CHANGE } & -0.00246070 & 0.0105735 & -0.2327 & 0.8170\end{array}$

$\begin{array}{lclr}\text { Mean dependent var } & 0.007953 & \text { S.D. dependent var } & 0.036611 \\ \text { Sum squared resid } & 0.061583 & \text { S.E. of regression } & 0.036994 \\ \text { R-squared } & 0.001202 & \text { Adjusted R-squared } & -0.020993 \\ \text { F(1, 45) } & 0.054160 & \text { P-value(F) } & 0.817032 \\ \text { Log-likelihood } & 89.29139 & \text { Akaike criterion } & -174.5828 \\ \text { Schwarz criterion } & -170.8825 & \text { Hannan-Quinn } & -173.1903 \\ \text { England Decline } & & & \\ \text { Model 1: OLS, using observations } & 1-51 & \\ \text { Dependent variable: GROWTH_RATE } & & \end{array}$

coefficient std. error t-ratio p-value

$\begin{array}{lllll}\text { const } & 0.0118477 & 0.00697946 & 1.698 & 0.0959 \text { * } \\ \text { TEMP_CHANGE } & 0.00546814 & 0.0105180 & 0.5199 & 0.6055\end{array}$

$\begin{array}{lcll}\text { Mean dependent var } & 0.009170 & \text { S.D. dependent var } & 0.033392 \\ \text { Sum squared resid } & 0.055445 & \text { S.E. of regression } & 0.033638 \\ \text { R-squared } & 0.005486 & \text { Adjusted R-squared } & -0.014811 \\ \text { F(1, 49) } & 0.270277 & \text { P-value (F) } & 0.605487 \\ \text { Log-likelihood } & 101.6508 & \text { Akaike criterion } & -199.3016 \\ \text { Schwarz criterion } & -195.4379 & \text { Hannan-Quinn } & -197.8252\end{array}$


France Increase

Model 1: OLS, using observations 1-37

Dependent variable: GROWTH_RATE

coefficient std. error t-ratio p-value

\begin{tabular}{|c|c|c|c|c|}
\hline const & 0.0273715 & 0.0109987 & 2.489 & 0.0177 \\
\hline EMP_CHANGE & -0.0443883 & 0.0197469 & -2.248 & 0.0310 \\
\hline
\end{tabular}

\begin{tabular}{|c|c|c|c|c|}
\hline Mean dependent var & 0.008038 & S.D. depe & rdent var & 0.043986 \\
\hline Sum squared resid & 0.060864 & S.E. of $r$ & gression & 0.041701 \\
\hline $\mathrm{R}$-squared & 0.126156 & Adjusted & R-squared & 0.101189 \\
\hline$F(1,35)$ & 5.052908 & P-value ( F & & 0.030987 \\
\hline Log-likelihood & 66.08475 & Akaike cr & terion & -128.1695 \\
\hline Schwarz criterion & -124.9477 & Hannan-Qu & $\ln n$ & -127.0336 \\
\hline $\begin{array}{l}\text { France Decline } \\
\text { Model 1: OLS, using }\end{array}$ & observatic & ns $1-42$ & & \\
\hline Dependent variable & GROWTH_RAT & & & \\
\hline $\mathrm{CO}$ & fficient & std. error & t-ratio & p-value \\
\hline const & 0233372 & 0.0122541 & 1.904 & 0.0641 \\
\hline TEMP_CHANGE & 0152699 & 0.0251545 & 0.6070 & 0.5473 \\
\hline Mean dependent var & 0.017437 & S.D. depe & dent var & 0.047989 \\
\hline Sum squared resid & 0.093559 & S.E. of $r$ & gression & 0.048363 \\
\hline R-squared & 0.009128 & Adjusted & R-squared & -0.015643 \\
\hline$F(1,40)$ & 0.368502 & P-value ( F & & 0.547252 \\
\hline Log-likelihood & 68.64801 & Akaike cr & terion & -133.2960 \\
\hline Schwarz criterion & -129.8207 & Hannan-Qu & $\ln n$ & -132.0222 \\
\hline
\end{tabular}


Germany Increase

Model 1: OLS, using observations 1-26

Dependent variable: GROWTH_RATE

coefficient std. error t-ratio p-value

$\begin{array}{lrrrrr}\text { const } & 0.0159628 & 0.00804400 & 1.984 & 0.0588 \text { * } \\ \text { TEMP_CHANGE } & -0.00780892 & 0.0165523 & -0.4718 & 0.6414\end{array}$

$\begin{array}{lclr}\text { Mean dependent var } & 0.012852 & \text { S.D. dependent var } & 0.023129 \\ \text { Sum squared resid } & 0.013251 & \text { S.E. of regression } & 0.023497 \\ \text { R-squared } & 0.009188 & \text { Adjusted R-squared } & -0.032095 \\ \text { F(1, 24) } & 0.222568 & \text { P-value(F) } & 0.641351 \\ \text { Log-likelihood } & 61.67064 & \text { Akaike criterion } & -119.3413 \\ \text { Schwarz criterion } & -116.8251 & \text { Hannan-Quinn } & -118.6167 \\ \begin{array}{l}\text { Germany Decline } \\ \text { Model 1: OLS, using }\end{array} & & \\ \text { Dependent variable: GRowTH_RATE } & & \end{array}$

coefficient std. error t-ratio p-value

$\begin{array}{lcccc}\text { const } & 0.0296594 & 0.0107131 & 2.769 & 0.0115 \\ \text { TEMP_CHANGE } & 0.0256177 & 0.0180049 & 1.423 & 0.1695\end{array}$ **

$\begin{array}{lcll}\text { Mean dependent var } & 0.017322 & \text { S.D. dependent var } & 0.030868 \\ \text { Sum squared resid } & 0.019120 & \text { S.E. of regression } & 0.030174 \\ \text { R-squared } & 0.087925 & \text { Adjusted R-squared } & 0.044493 \\ \text { F(1, 21) } & 2.024419 & \text { P-value (F) } & 0.169474 \\ \text { Log-likelihood } & 48.92863 & \text { Akaike criterion } & \mathbf{- 9 3 . 8 5 7 2 6} \\ \text { Schwarz criterion } & -91.58627 & \text { Hannan-Quinn } & \mathbf{- 9 3 . 2 8 6 1 1}\end{array}$


Holland Increase

Model 1: OLS, using observations 1-47

Dependent variable: GROWTH_RATE

coefficient std. error t-ratio p-value

$\begin{array}{lllll}\text { const } & 0.00149402 & 0.00595098 & 0.2511 & 0.8029 \\ \text { TEMP_CHANGE } & 0.0117346 & 0.0107941 & 1.087 & 0.2828\end{array}$

$\begin{array}{lcll}\text { Mean dependent var } & 0.006527 & \text { S.D. dependent var } & 0.025684 \\ \text { Sum squared resid } & 0.029569 & \text { S.E. of regression } & 0.025634 \\ \text { R-squared } & 0.025591 & \text { Adjusted R-squared } & 0.003938 \\ \text { F(1, 45) } & 1.181848 & \text { P-value(F) } & 0.282769 \\ \text { Log-likelihood } & 106.5327 & \text { Akaike criterion } & -209.0653 \\ \text { Schwarz criterion } & -205.3650 & \text { Hannan-Quinn } & -207.6729 \\ \text { Holland Decline } & & & \\ \text { Model 1: OLS, using observations } & 1-37 & \\ \text { Dependent variable: GROWTH_RATE } & \end{array}$

coefficient std. error t-ratio p-value

$\begin{array}{lllll}\text { const } & 0.00955534 & 0.0107399 & 0.8897 & 0.3797 \\ \text { TEMP_CHANGE } & 0.00107493 & 0.0155336 & 0.06920 & 0.9452\end{array}$

$\begin{array}{lclr}\text { Mean dependent var } & 0.008935 & \text { S.D. dependent var } & 0.035473 \\ \text { Sum squared resid } & 0.045295 & \text { S.E. of regression } & 0.035974 \\ \text { R-squared } & 0.000137 & \text { Adjusted R-squared } & -0.028431 \\ \text { F(1, 35) } & 0.004789 & \text { P-value (F) } & 0.945224 \\ \text { Log-likelihood } & 71.55066 & \text { Akaike criterion } & -139.1013 \\ \text { Schwarz criterion } & -135.8795 & \text { Hannan-Quinn } & -137.9655\end{array}$


Italy Increase

Model 1: OLS, using observations 1-50

Dependent variable: GROWTH_RATE

coefficient std. error t-ratio p-value

$\begin{array}{lcccc}\text { const } & -0.000302822 & 0.00716145 & -0.04228 & 0.9664 \\ \text { TEMP_CHANGE } & 0.00533018 & 0.0109299 & 0.4877 & 0.6280\end{array}$

$\begin{array}{lclr}\text { Mean dependent var } & 0.002480 & \text { S.D. dependent var } & 0.030359 \\ \text { Sum squared resid } & 0.044940 & \text { S.E. of regression } & 0.030598 \\ \text { R-squared } & 0.004930 & \text { Adjusted R-squared } & -0.015800 \\ \text { F(1, 48) } & 0.237822 & \text { P-value(F) } & 0.628004 \\ \text { Log-likelihood } & 104.4142 & \text { Akaike criterion } & -204.8285 \\ \text { Schwarz criterion } & -201.0044 & \text { Hannan-Quinn } & -203.3723\end{array}$

Italy Decline

Model 1: OLS, using observations 1-48

Dependent variable: GROWTH_RATE

coefficient std. error t-ratio p-value

$\begin{array}{lllll}\text { const } & -0.00205080 & 0.00575583 & -0.3563 & 0.7232 \\ \text { TEMP_CHANGE } & -0.00956387 & 0.00765617 & -1.249 & 0.2179\end{array}$

$\begin{array}{lcll}\text { Mean dependent var } & 0.003404 & \text { S.D. dependent var } & 0.026132 \\ \text { Sum squared resid } & 0.031042 & \text { S.E. of regression } & 0.025978 \\ \text { R-squared } & 0.032809 & \text { Adjusted R-squared } & 0.011784 \\ \text { F(1, 46) } & 1.560429 & \text { P-value(F) } & 0.217922 \\ \text { Log-likelihood } & 108.1374 & \text { Akaike criterion } & -212.2748 \\ \text { Schwarz criterion } & -208.5324 & \text { Hannan-Quinn } & -210.8606\end{array}$


Norway Increase

Model 1: OLS, using observations 1-39

Dependent variable: GROWTH_RATE

coefficient std. error t-ratio p-value

$\begin{array}{lrrrrr}\text { const } & 0.0177670 & 0.00778256 & 2.283 & 0.0283 \\ \text { TEMP_CHANGE } & -0.00771691 & 0.00921724 & -0.8372 & 0.4078\end{array}$ **

$\begin{array}{lclc}\text { Mean dependent var } & 0.012449 & \text { S.D. dependent var } & 0.027977 \\ \text { Sum squared resid } & 0.029190 & \text { S.E. of regression } & 0.028088 \\ \text { R-squared } & 0.018592 & \text { Adjusted R-squared } & -0.007932 \\ \text { F(1, 37) } & 0.700946 & \text { P-value (F) } & 0.407841 \\ \text { Log-likelihood } & 85.01232 & \text { Akaike criterion } & -166.0246 \\ \text { Schwarz criterion } & -162.6975 & \text { Hannan-Quinn } & -164.8309\end{array}$

Norway Decline

Model 1: OLS, using observations 1-30

Dependent variable: GROWTH_RATE

coefficient std. error t-ratio p-value

$\begin{array}{llllll}\text { const } & 0.0385427 & 0.0110044 & 3.502 & 0.0016 & \star * \star \\ \text { TEMP_CHANGE } & 0.0303337 & 0.0104784 & 2.895 & 0.0073 * \star *\end{array}$

$\begin{array}{lcll}\text { Mean dependent var } & 0.012130 & \text { S.D. dependent var } & 0.037743 \\ \text { Sum squared resid } & 0.031795 & \text { S.E. of regression } & 0.033698 \\ \text { R-squared } & 0.230355 & \text { Adjusted R-squared } & 0.202868 \\ \text { F(1, 28) } & 8.380413 & \text { P-value (F) } & 0.007273 \\ \text { Log-likelihood } & 60.17635 & \text { Akaike criterion } & -116.3527 \\ \text { Schwarz criterion } & -113.5503 & \text { Hannan-Quinn } & -115.4562\end{array}$


Sweden Increase

Model 1: OLS, using observations 1-52

Dependent variable: GROWTH_RATE

coefficient std. error t-ratio p-value

$\begin{array}{lrrrrr}\text { const } & 0.0191563 & 0.00722601 & 2.651 & 0.0107 \\ \text { TEMP_CHANGE } & -0.00943865 & 0.00778689 & -1.212 & 0.2312\end{array}$ **

$\begin{array}{lcll}\text { Mean dependent var } & 0.012323 & \text { S.D. dependent var } & 0.032744 \\ \text { Sum squared resid } & 0.053121 & \text { S.E. of regression } & 0.032595 \\ \text { R-squared } & 0.028546 & \text { Adjusted R-squared } & 0.009117 \\ \text { F(1, 50) } & 1.469237 & \text { P-value (F) } & 0.231163 \\ \text { Log-likelihood } & 105.2625 & \text { Akaike criterion } & -206.5250 \\ \text { Schwarz criterion } & -202.6225 & \text { Hannan-Quinn } & -205.0289\end{array}$

Sweden decline

Model 1: OLS, using observations 1-45

Dependent variable: GROWTH_RATE

coefficient std. error t-ratio p-value

$\begin{array}{lllll}\text { const } & 0.00691520 & 0.0101431 & 0.6818 & 0.4990 \\ \text { TEMP_CHANGE } & 0.00102638 & 0.00959589 & 0.1070 & 0.9153\end{array}$

$\begin{array}{lclr}\text { Mean dependent var } & 0.006031 & \text { S.D. dependent var } & 0.038970 \\ \text { Sum squared resid } & 0.066804 & \text { S.E. of regression } & 0.039415 \\ \text { R-squared } & 0.000266 & \text { Adjusted R-squared } & -0.022984 \\ \text { F(1, 43) } & 0.011440 & \text { P-value (F) } & 0.915318 \\ \text { Log-likelihood } & 82.68250 & \text { Akaike criterion } & -161.3650 \\ \text { Schwarz criterion } & -157.7517 & \text { Hannan-Quinn } & -160.0180\end{array}$


Switzerland Increase

Model 1: OLS, using observations 1-19

Dependent variable: GROWTH_RATE

coefficient std. error t-ratio p-value

$\begin{array}{lllll}\text { const } & 0.0294739 & 0.0417719 & 0.7056 & 0.4900 \\ \text { TEMP_CHANGE } & 0.0339113 & 0.0710638 & 0.4772 & 0.6393\end{array}$

$\begin{array}{lcll}\text { Mean dependent var } & 0.044453 & \text { S.D. dependent var } & 0.117526 \\ \text { Sum squared resid } & 0.245335 & \text { S.E. of regression } & 0.120131 \\ \text { R-squared } & 0.013218 & \text { Adjusted R-squared } & -0.044828 \\ \text { F(1, 17) } & 0.227715 & \text { P-value(F) } & 0.639301 \\ \text { Log-likelihood } & 14.36106 & \text { Akaike criterion } & -24.72213 \\ \text { Schwarz criterion } & -22.83325 & \text { Hannan-Quinn } & -24.40246 \\ \text { Switzerland Decline } & & & \\ \text { Model 1: OLS, using observations } & \text { 1-29 } & \\ \text { Dependent variable: GROWTH_RATE } & & \end{array}$

coefficient std. error t-ratio p-value

$\begin{array}{lllll}\text { const } & 0.0235059 & 0.0304762 & 0.7713 & 0.4472 \\ \text { TEMP_CHANGE } & 0.0433649 & 0.0812356 & 0.5338 & 0.5978\end{array}$

$\begin{array}{lclr}\text { Mean dependent var } & 0.009924 & \text { S.D. dependent var } & 0.089180 \\ \text { Sum squared resid } & 0.220360 & \text { S.E. of regression } & 0.090341 \\ \text { R-squared } & 0.010444 & \text { Adjusted R-squared } & -0.026206 \\ \text { F(1, 27) } & 0.284960 & \text { P-value (F) } & 0.597836 \\ \text { Log-likelihood } & 29.60770 & \text { Akaike criterion } & -55.21540 \\ \text { Schwarz criterion } & -52.48080 & \text { Hannan-Quinn } & -54.35896\end{array}$

